\title{
PERBANDINGAN PENGGUNAAN MODEL PEMBELAJARAN INVESTIGASI KELOMPOK DENGAN MODEL PEMBELAJARAN OBSERVASI TERHADAP HASIL BELAJAR SISWA SMP NEGERI 2 KUALUH SELATAN
}

\author{
Rahmi Nazliah (rahmi.nazliah@yahoo.com) \\ Program Studi Pendidikan Biologi, \\ Sekolah Tinggi dan Ilmu Pendidikan (STKIP) Labuhanbatu \\ Jalan Sisingamangaraja no.126 A Km 3,5 Aek Tapa, Bakaran Batu Kab. Labuhanbatu
}

\begin{abstract}
ABSTRAK
Penelitian ini bertujuan untuk mengetahui perbedaan hasil belajar, pada materi sistem gerak pada manusia yang dibelajarkan dengan model pembelajaran Investigasi Kelompok dan model pembelajaran Observasi di kelas VIII SMP Negeri 2 Kualuh Selatan. Penelitian ini menggunakan metode quasi eksperimen dengan sampel penelitian ditentukan secara acak dengan teknik random sampling. Kelas VIIIA dibelajarkan dengan model pembelajaran Investigasi Kelompok dan kelas VIII-B dibelajarkan dengan model pembelajaran Observasi. Instrumen penelitian menggunakan tes hasil belajar bentuk pilihan ganda. Teknik analisis data menggunakan uji t tidak berpasangan dan uji korelasi Pearson pada taraf signifikansi $\alpha=0,05$ dengan bantuan aplikasi SPSS 20.0. Hasil penelitian menunjukkan bahwa hasil belajar siswa yang dibelajarkan dengan Investigasi Kelompok lebih tinggi daripada siswa yang dibelajarkan dengan Observasi dengan rata-rata $(79,67: 67,33)$ walaupun secara statistik tidak berbeda nyata $(t=4,890 ; P=0,000>0,05)$. Sebagai tindak lanjut, diharapkan kepada guru untuk dapat menerapkan model pembelajaran Investigasi Kelompok dalam pembelajaran biologi pada pokok materi sistem gerak pada manusia dalam upaya meningkatkan hasil belajar siswa.
\end{abstract}

Kata Kunci: Kata kunci: Investigasi Kelompok, Observasi, Hasil Belajar.

\begin{abstract}
The aim of the study was to determine the difference in learning outcome, in the material system of motion in humans that was learned by the Group Investigation learning model and Observation learning model in class VIII SMP Negeri 2 Kualuh Selatan. The research method used in this study was a quasiexperimental method with the research sample determined randomly by random sampling technique. Class VIIIA was taught with the Group Investigation learning model and class VIII-B was taught with the Observation learning model. The research instrument used in this study was multiple choice form learning test. The technique of data analysis used in this study were unpaired t test and Pearson correlation test at a significance level $\alpha=0.05$ with the help of SPSS 20.0. The results showed that the learning outcomes of students who were studied with Group Investigation were higher than those studied by Observation with average (79.67: 67.33) although statistically not significantly different $(t=4,890 ; P=0,000>0,05)$. As a follow-up, expected to teachers to be able to apply the Group Investigation learning model in learning biology on the subject of motion systems in humans in an effort to improve student learning outcomes.
\end{abstract}

Keywords: Group Investigation, Observation, Learning Outcome

\section{PENDAHULUAN}

Peningkatan mutu pendidikan ada salah satu pendekatan yang harus dilalui dengan sukses, yaitu: pendekatan substansial pendidikan (content approach). Pendekatan ini berkaitan langsung dengan mutu pendidikan dan tingkah laku yang harus dimiliki oleh anak didik, karena proses belajar mengajar yang berpusat pada siswa (student centered), bukan didominasi oleh guru (teacher centered). Permasalahan yang dihadapi dunia pendidikan Indonesia saat ini adalah lemahnya proses pembelajaran. Proses pembelajaran di kelas hanya diarahkan kepada kemampuan siswa untuk menghafal infomasi. Pada dasarnya proses pembelajaran itu merupakan salah satu transformasi pengetahuan, sikap dan keterampilan dengan melibatkan aktivitas fisik dan juga mental siswa. Keterlibatan siswa baik secara fisik maupun secara mental merupakan bentuk pengalaman belajar yang memperkuat pemahaman yang dimiliki siswa terhadap konsep pembelajaran. 
Permasalahan yang dihadapi dunia pendidikan Indonesia saat ini adalah lemahnya proses pembelajaran. Proses pembelajaran di kelas hanya diarahkan kepada kemampuan siswa untuk menghafal infomasi. Pada dasarnya proses pembelajaran itu merupakan salah satu transformasi pengetahuan, sikap dan keterampilan dengan melibatkan aktivitas fisik dan juga mental siswa. Keterlibatan siswa baik secara fisik maupun secara mental merupakan bentuk pengalaman belajar yang memperkuat pemahaman yang dimiliki siswa terhadap konsep pembelajaran. Sebagai tenaga pendidik yang profesional guru diharapkan mampu untuk memilih dan juga menggunakan model pembelajaran yang sesuai dengan materi pelajaran, sehingga guru dapat meningkatkan hasil belajar siswa, (Kamaruddin, 2014:54). Berdasarkan hasil penelitian yang dilakukan oleh Kamaruddin (2014) yang bertujuan untuk meningkatkan minat, motivasi dan hasil belajar siswa dengan menggunakan model pembelajaran investigasi kelompok dan observasi ternyata siswa yang dibelajarkan memiliki hasil yang lebih baik dan meningkat.

Model pembelajaran observasi merupakan model pembelajaran yang melibatkan keaktifan siswa untuk menemukan konsep. Observasi merupakan bagian inti dari kegiatan pembelajaran berbasis kontekstual. Pengetahuan dan keterampilan yang diperoleh siswa diharapkan bukan hasil mengingat seperangkat fakta-fakta akan tetapi menemukan sendiri. Banyak model pembelajaran yang ada, model pembelajaran investigasi kelompok (group investigation) dan model pembelajaran observasi yang memiliki dasar filosofi konstruktivisme, mampu mendorong siswa untuk membangun pengetahuannya sendiri dan meningkatkan hasil belajar siswa.

Kenyataan di lapangan menunjukkan masih banyak rendahnya hasil belajar siswa belum ditangani secara sungguh-sungguh oleh tenaga pendidik di sekolah sehingga masih banyak siswa yang kurang terampil dalam menggunakan yang berdampak pada hasil belajar siswa yang rendah. Hal ini didukung dengan pernyataan Ariyati (2010:56) bahwa rendahnya kualitas pendidikan disebabkan karena rendahnya hasil belajar siswa.

Hasil observasi penulis dengan guru biologi di SMP Negeri 2 Kualuh Selatan diketahui bahwa siswa masih memiliki nilai rata-rata yang rendah, terlihat dari minat, motivasi belajar siswa dan nilai-nilai hasil belajar siswa. Guru tidak menggunakan variasi dalam mengajar, dimana guru masih menggunakan model pembelajaran konvensional berupa metode ceramah. Sehingga siswa menganggap mata pelajaran biologi merupakan mata pelajaran yang membosankan.

Untuk mengatasi berbagai permasalahan di atas, diperlukan proses pembelajaran di kelas lebih efektif dan siswa terlibat secara aktif dalam proses pembelajaran serta dapat meningkatkan hasil belajar siswa maka guru harus mampu untuk memilih dan menerapkan model pembelajaran ideal yang dapat mengarahkan dan menuntut siswa untuk membentuk pengetahuannya. Jadi peran guru dalam proses pembelajaran adalah membantu agar proses pembentukan pengetahuan oleh siswa dapat berjalan dengan baik.

Berdasarkan pemaparan di atas, perlu dilakukan suatu penelitian dengan Perbandingan Penggunaan Model Pembelajaran Investigasi Kelompok Dengan Model Pembelajaran Observasi Terhadap Hasil Belajar Siswa SMP Negeri 2 Kualuh Selatan.

\section{METODE PENELITIAN}

Yang menjadi populasi dalam penelitian ini adalah seluruh kelas VIII SMP Negeri 2 Kualuh Selatan dengan jumlah 3 kelas dan jumlah keseluruhan 90 siswa. Sampel dalam penelitian ini sebanyak 2 kelas yaitu kelas VIIIA sebagai kelas yang dibelajarkan dengan menggunakan model pembelajaran investigasi kelompok (group investigation) dan kelas VIII ${ }^{\mathrm{B}}$ sebagai kelas yang dibelajarkan dengan menggunakan model pembelajaran observasi. Dengan demikian jumlah sampel keseluruhan adalah 60 orang siswa. Dalam menentukan sampel penelitian, peneliti menggunakan random sampling. Penelitian ini bersifat quasi eksperimen. Dalam penelitian ini dilaksanakan perlakuan terhadap dua kelas eksperimen. Rancangan penelitian seperti pada tabel berikut:

Tabel 1. Rancangan Penelitian.

\begin{tabular}{cccc}
\hline Kelas & $\begin{array}{c}\text { Tes } \\
\text { Awal }\end{array}$ & Perlakuan & $\begin{array}{c}\text { Tes } \\
\text { Akhir }\end{array}$ \\
\hline $\begin{array}{c}\text { Eksperimen 1 } \\
\text { (Model Pembelajaran } \\
\text { GI) }\end{array}$ & $\mathrm{T}_{1}$ & $\mathrm{X}_{1}$ & $\mathrm{~T}_{2}$ \\
\hline $\begin{array}{c}\text { Eksperimen 2 } \\
\text { (Model Pembelajaran } \\
\text { Observasi) }\end{array}$ & $\mathrm{T}_{1}$ & $\mathrm{X}_{2}$ & $\mathrm{~T}_{2}$ \\
$\begin{array}{c}\text { Ket : } \mathrm{T}_{1}=\text { Tes awal (pre-tes) } \\
\mathrm{T}_{2}=\text { Tes Akhir (post-tes) }\end{array}$ & & \\
\end{tabular}


$\mathrm{X}_{1}=$ Pengajaran model investigasi kelompok

$\mathrm{X}_{2}=$ Pengajaran model observasi

Instrumen atau alat pengumpulan data dalam penelitian ini menggunakan tes berbentuk pilihan berganda sebanyak 30 soal. Penyusunan tes berpedoman pada materi pokok sistem gerak pada manusia pada aspek kognitif Taksonomi Bloom terdiri atas aspek pengetahuan (C1), pemahaman (C2), aplikasi (C3) Analisis (C4). Setiap jawaban yang benar diberi skor 1 sedangkan yang salah diberi skor 0 . Tes hasil belajar siswa yang digunakan untuk mengukur hasil belajar kognitif siswa terlebih dahulu diujicobakan untuk mengetahui validitas, reliabilitas, daya beda dan tingkat kesukarannya.

Pengujian validitas adan reliabilitas instrumen tes hasil belajar mahasiswa dilakukan dengan bantuan program komputer microsoft Excel. Begitu juga untuk uji daya beda dan tingkat kesukaran tes dilakukan dengan bantuan program komputer microsoft Excel. Penelitian ini menggunakan teknik analisis data berupa analisis deskriptif dan analisis inferensial Analisis statistik inferensial dilakukan untuk menguji hipotesis penelitian, yang terlebih dahulu dilakukan uji prasyarat terhadap data yang dikumpulkan dengan menggunakan uji normalitas dan homogenitas.

\section{HASIL DAN PEMBAHASAN}

Deskripsi Hasil Belajar Pos-tes Model Pembelajaran Investigasi Kelompok dan Model Pembelajaran Observasi.

Sebelum melakukan pembelajaran dengan menggunakan model pembelajaran investigasi kelompok dan model pembelajaran observasi terlebih dahulu dilakukan pre-tes (tes awal) yang tujuannya untuk mengetahui kemampuan awal dari siswa tanpa dipengaruhi pembelajaran. Dimana yang meliputi hasil pre-tes terendah hingga tertinggi, rata-rata nilai, standart deviasi, varians.

Tabel 2. Data hasil belajar siswa sebelum dilakukan pembelajaran pada kelas Investigasi Kelompok dan kelas Observasi.

\begin{tabular}{lccccc}
\hline $\begin{array}{c}\text { Model Pem- Pretes } \\
\text { belajaran }\end{array}$ & $\begin{array}{c}\text { Pretes } \\
\text { tinggi }\end{array}$ & $\begin{array}{c}\text { Te } \\
\text { rendah }\end{array}$ & Mean & $\begin{array}{c}\text { Std. } \\
\text { Dev }\end{array}$ & $\begin{array}{c}\text { Vari } \\
\text { ans }\end{array}$ \\
\hline $\begin{array}{c}\text { Investigasi } \\
\text { Kelompok }\end{array}$ & 47 & 60 & 48,33 & 6,98 & 48,85 \\
\hline Observasi & 30 & 67 & 45,00 & 7,87 & 62,06 \\
\hline
\end{tabular}

Hasil tabel menunjukkan bahwa rata-rata pretes siswa sebelum dibelajarkan dengan menggunakan model pembelajaran Investigasi Kelompok dan model pembelajaran observasi pada materi sistem gerak pada manusia nilai rata-rata pretes siswa pada kelas model pembelajaran Investigasi Kelompok sebesar 48,33 dengan standar deviasi 6,98 dan varians sebesar 48,851. Sedangkan rata-rata pretes siswa pada kelas model pembelajaran observasi sebesar 45,00 dengan standart deviasi 7,87 dan varians sebesar 62,06.

Namun model pembelajaran Investigasi Kelompok dan Observasi sebagai berikut ini :

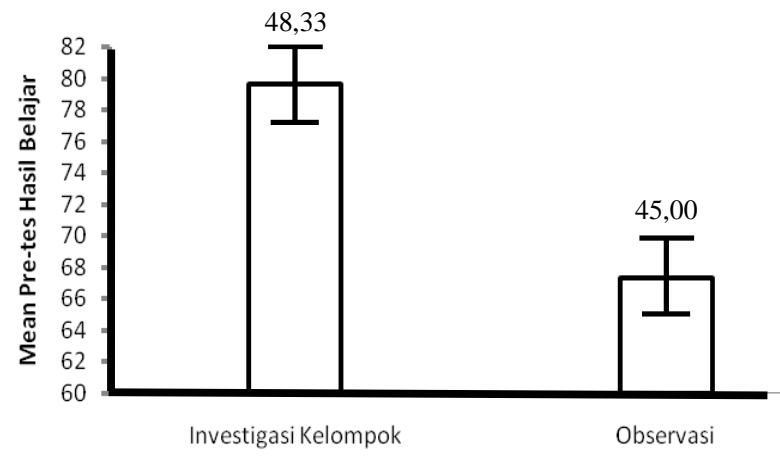

Kelas Model Pembelajaran

Gambar 1. Perbandingan Pre-tes Hasil Belajar Siswa Kelas Model Pembelajaran Investigasi Kelompok dan Kelas Model Pembelajaran Observasi.

\section{Deskripsi Hasil Belajar Post - tes Kelas Model Pembelajaran Investigasi Kelompok dan Kelas Model Pembelajaran Observasi}

Setelah dibelajarkan dengan menggunakan model pembelajaran investigasi kelompok dan model pembelajaran observasi pada materi sistem gerak manusia. Maka diperoleh nilai pos-tes hasil belajar siswa, dimana Pos-tes (Po) terendah (Tr) hingga tertinggi $(\mathrm{Tt})$, rata-rata nilai, standart deviasi, varians.

Tabel 3. Data hasil belajar siswa setelah dibelajarkan dengan Model Pembelajaran Investigasi Kelompok dan Model Pembelajaran Observasi.

\begin{tabular}{lccccc}
\hline $\begin{array}{c}\text { Model Pem } \\
\text { belajaran }\end{array}$ & $\begin{array}{c}\text { Post-tes Post-tes } \\
\text { Ter } \\
\text { endah }\end{array}$ & $\begin{array}{c}\text { Ter } \\
\text { tinggi }\end{array}$ & Mean & $\begin{array}{c}\text { Std. } \\
\text { Dev }\end{array}$ & Varians \\
\hline $\begin{array}{c}\text { Investigasi } \\
\text { Kelompok }\end{array}$ & 50 & 95 & 79,67 & 10,417 & 108,51 \\
\hline Observasi & 50 & 90 & 67,33 & 9,072 & 82,30 \\
\hline
\end{tabular}

Hasil tabel menunjukkan bahwa rata-rata pos-tes siswa setelah dibelajarkan dengan menggunakan model pembelajaran Investigasi Kelompok dan model pembelajaran observasi pada materi sistem gerak pada manusia nilai rata-rata 
pretes siswa pada kelas model pembelajaran Investigasi Kelompok sebesar 79,67 dengan standar deviasi 10,417 dan varians sebesar 108,506 . Sedangkan rata-rata pos-tes siswa pada kelas model pembelajaran observasi sebesar 67,33 dengan standart deviasi 9,072 dan varians sebesar 82,299. Selanjutnya hasil menunjukkan bahwa hasil belajar biologi siswa pada kelas model pembelajaran Investigasi Kelompok 79,67士10,417 lebih tinggi dibandingkan hasil belajar siswa pada kelas model pembelajaran observasi $67,33 \pm 9,072$ namun tidak berbeda signifikan.

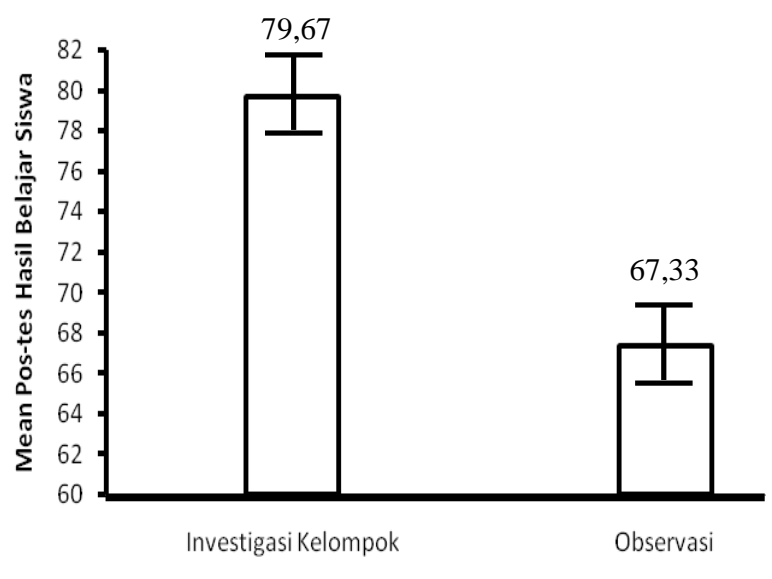

Kelas Model Pembelajaran

Gambar 2. Perbandingan Pos-tes Hasil Belajar Siswa Kelas Model Pembelajaran Investigasi Kelompok dan Kelas Model Pembelajaran Observasi.

Dari diagram di atas menunjukkan terdapat perbedaan yang signifikan. Hal ini berarti hipotesis nul $\left(\mathrm{H}_{0}\right)$ ditolak dan hipotesis alternatif $\left(\mathrm{H}_{\mathrm{a}}\right)$ diterima. Artinya terdapat perbedaan model pembelajaran Investigasi Kelompok dengan Model Pembelajaran Observasi terhadap hasil belajar siswa dalam mempelajari materi sistem gerak manusia diterima.

\section{Uji Normalitas}

Uji normalitas digunakan untuk menguji apakah dalam sebuah model Npar Tests mempunyai distribusi normal atau tidak. Model Npar Tests yang baik adalah memiliki distribusi normal atau mendekati normal. Berdasarkan data yang diperoleh dari perhitungan hasil uji Kolmogorof-Smirnov dinyatakan bahwa kemampuan awal siswa kelas investigasi kelompok memiliki sebaran data berdistribusi normasl $(Z=1,246 ; \quad P=0,089)$. Sedangkan data kemampuan awal siswa kelas observasi memiliki sebaran data berdistribusi normal $(Z=1,299$; $\mathrm{P}=0,068$ ). Selanjutnya dari hasil pos-tes pada kelas investigasi kelompok memiliki sebaran data berdistribusi normal $(\mathrm{Z}=1,165 ; \quad \mathrm{P}=0,132)$. Sedangkan data pos-tes kelas observasi memiliki sebaran data berdistribusi normal $(Z=1,193$; $\mathrm{P}=0,116)$.

\section{Uji Homogenitas}

Uji homogenitas digunakan untuk menguji apakah dalam sebuah model t-test data homogen apakah tidak. Apabila homogenitas terpenuhi maka peneliti dapat melakukan pada tahap analisa data lanjutan, apabila tidak maka harus ada pembetulan-pembetulan metodologis. Berdasarkan data yang diperoleh dari perhitungan hasil uji Kolmogorof-Smirnov dapat dilihat homogenitas melalui nilai signifikan. Jika nilai signifikan $>0,05$ maka data bisa dikatakan homogen. Tabel uji homogenitas menunjukkan signifikan 0,002 yang berarti > 0,05, sehingga data bisa dikatakan homogen.

Tabel 4. Perhitungan $t$-test dengan SPSS 20.0

\begin{tabular}{|c|c|c|c|c|c|c|c|c|c|c|}
\hline & & \multicolumn{2}{|c|}{$\begin{array}{c}\text { Levene's Test } \\
\text { for Equality of } \\
\text { Variances }\end{array}$} & \multicolumn{7}{|c|}{ t-test for Equality of Means } \\
\hline & & \multirow[t]{2}{*}{$\bar{F}$} & \multirow[t]{2}{*}{ Sig. } & \multirow[t]{2}{*}{$\mathrm{t}$} & \multirow[t]{2}{*}{$\mathrm{df}$} & \multirow[t]{2}{*}{$\begin{array}{c}\text { Sig. } \\
\text { (2-tailed) }\end{array}$} & \multirow[t]{2}{*}{$\begin{array}{c}\text { Mean } \\
\text { Difference }\end{array}$} & \multirow{2}{*}{$\begin{array}{c}\text { Std. } \\
\text { Error } \\
\text { Differe } \\
\text { nce }\end{array}$} & \multicolumn{2}{|c|}{$\begin{array}{l}\text { 95\% Confidence } \\
\text { Interval of the } \\
\text { Difference }\end{array}$} \\
\hline & & & & & & & & & Lower & Upper \\
\hline \multirow[t]{2}{*}{$\begin{array}{c}\text { Postes Hasil } \\
\text { Belajar }\end{array}$} & $\begin{array}{c}\text { Equal variances } \\
\text { assumed }\end{array}$ & ,002 & ,968 & 4,890 & 58 & ,000 & 12,333 & 2,522 & 7,285 & 17,382 \\
\hline & $\begin{array}{c}\text { Equal variances } \\
\text { not assumed }\end{array}$ & & & 4,890 & 56,926 & ,000 & 12,333 & 2,522 & 7,283 & 17,384 \\
\hline
\end{tabular}




\section{Uji Hipotesis}

Pengujian hipotesis dilakukan dengan menggunakan Independent samples tes dimana ternyata $t_{\text {tabel }}=\mathrm{df}, a / 2 \quad(60,0.025)$, berarti $t_{\text {tabel }}=2,00,<t_{\text {hitung }}=4,890$, maka Ha diterima. Dari hasil analisa di atas maka dapat diambil kesimpulan bahwa ada perbandingan model pembelajaran investigasi kelompok dengan pembelajaran observasi terhadap hasil belajar kelas VIII SMP Negeri 2 Kualuh Selatan tentang sistem gerak pada manusia. Dapat dilihat dari table 4 diatas.

\section{PEMBAHASAN}

\section{Perbedaan Hasil Belajar Siswa yang Dibelajarkan dengan Model Pembelajaran Investigasi Kelompok dan Model Pembelajaran Observasi.}

Hasil perhitungan uji t (independent $t$ test) untuk pretest hasil belajar siswa tentang sistem gerak pada manusia sebelum pembelajaran pada kelas Investigasi Kelompok dan kelas Observasi, diperoleh nilai $\mathrm{t}=1,734$ dengan probabilitas, $\mathrm{P}=$ 0,088. Dikarenakan nilai $\mathrm{P}>0,05$ maka data pretest hasil belajar siswa tentang sistem gerak pada manusia pada kelas Investigasi Kelompok dan kelas Observasi sebelum pembelajaran adalah sama atau kedua rata-rata nilai kelas Investigasi Kelompok dan kelas Observasi identik. Artinya tidak terdapat perbedaan kemampuan awal siswa tentang sistem gerak pada manusia pada kelas investigasi kelompok dan kelas observasi. Setelah kegiatan pembelajaran tentang sistem gerak pada manusia dengan menggunakan model pembelajaran investigasi kelompok dan model pembelajaran observasi dilakukan pada kelas investigasi kelompok dan kelas observasi diperoleh data posttest hasil belajar siswa yang selanjutnya dianalisis kembali dengan uji t (independent $t$ test) sehingga diketahui bahwa nilai $t=4,890$ dengan probabilitas, $\mathrm{P}=0,000$ yang berarti nilai $\mathrm{P}>0,05$. Artinya $\mathrm{H}_{0}$ diterima dan $\mathrm{H}_{\mathrm{a}}$ ditolak. Berdasarkan pengujian uji t terhadap data hasil belajar kelas investigasi kelompok dan kelas observasi dapat dinyatakan tidak terdapat perbedaan yang signifikan hasil belajar siswa SMP Negeri 2 Kualuh Selatan tentang sistem gerak pada manusia yang dibelajarkan dengan model pembelajaran investigasi kelompok dan model pembelajaran observasi).

\section{Hasil Belajar Siswa yang Dibelajarkan dengan Model Pembelajaran Investigasi Kelompok dan Model Pembelajaran Observasi \\ Berdasarkan analisis data, secara} keseluruhan hasil belajar kelompok siswa yang dibelajarkan dengan model pembelajaran investigasi kelompok memperoleh rata-rata nilai $(\bar{X}=79,67)$ lebih tinggi daripada kelompok siswa yang dibelajarkan dengan model pembelajaran observasi $(\bar{X}=67,33)$. Kemudian setelah dianalisis dengan uji $\mathrm{t}$ (independent $t$ test) antara kelas investigasi kelompok dan kelas observasi, maka diperoleh nilai $(\mathrm{t}=4,890 ; \mathrm{P}=0,000>0,05)$. Dikarenakan nilai $\mathrm{P}>0,05$ maka artinya tidak terdapat perbedaan yang signifikan hasil belajar siswa tentang sistem gerak pada manusia yang dibelajarkan dengan model pembelajaran investigasi kelompok dan model pembelajaran observasi.

Dalam penelitian ini ditemukan bahwa model pembelajaran investigasi kelompok dan observasi mempunyai kemampuan yang sama baiknya dalam meningkatkan hasil belajar siswa tentang sistem gerak pada manusia. Hal ini ditunjukkan oleh uji statistik yang memperlihatkan bahwa tidak adanya perbedaan antara keduanya dalam mempengaruhi hasil belajar siswa. Namun demikian nilai hasil belajar siswa pada kelas investigasi kelompok lebih tinggi dibandingkan dengan kelas observasi sebanyak 7,34\% (79,67:67,33). Maka berikut ini akan dibahas kegiatan proses pembelajaran yang berlangsung pada kelas investigasi kelompok dan kelas observasi.

Penggunaan model pembelajaran investigasi kelompok membuat siswa lebih cepat memperoleh pengetahuan karena siswa di kelompokkan secara homogen untuk melakukan diskusi dengan demikian siswa dapat menemukan jawaban dari materi-materi yang diberikan oleh guru. Situasi saat proses belajar mengajar menjadi suatu hal yang menyenangkan bagi siswa maupun peneliti. Hal ini tentu saja ada perbebedaan terhadap hasil belajar siswa yang memang lebih tinggi dibandingkan dengan kelas pembelajaran observasi yang masih sulit dalam mengontrol siswa untuk dapat belajar.

\section{SIMPULAN}

Berdasarkan hasil penelitian dan pengujian analisis data, maka dapat diambil beberapa 
simpulan sebagai berikut: Hasil belajar siswa yang diajarkan dengan model pembelajaran investigasi kelompok pada materi sistem gerak pada manusia dikelas VIII SMP Negeri 2 Kualuh Selatan, masingmasing $\bar{X}=79,67$; Standar Deviasi $=10,41$. Hasil belajar siswa yang diajarkan dengan model pembelajaran observasi pada materi sistem gerak pada manusia dikelas VIII SMP Negeri 2 Kualuh Selatan masing-masing $\bar{X}=67,33$; Standar Deviasi $=9,07$.

Ada perbedaan hasil belajar yang signifikan antara siswa yang diajarkan dengan model pembelajaran Investigasi Kelompok dengan model pembelajaran Observasi pada materi sistem gerak pada manusia dikelas VIII SMP Negeri 2 Kualuh Selatan. Dengan taraf signifikan $\alpha=0,05$ dengan $t_{\text {hitung }}>t_{\text {tabel }}(4,890>0,000)$.

\section{REFERENSI}

Arends, Richard I. (2008). Learning to Teach. Jakarta: Pustaka Belajar.

Anon. (2010). Pengajaran Berdasarkan Masalah. Surabaya: University Press.

Akinoglu, O., Ruhan, U. (2007). The Effects of Problem-based active learning in Science education on Student's academic achievement, attitude and concept learning, Eurasia Journal of Mathematics, Science and Technology Education, Volume 3 (1) : Halaman 71 - 78.

Djamarah, (2009), Strategi Belajar Mengajar, Jakarta: Rineka Cipta Karya.

Dimyanti. (2009), Belajar dan Hasil Pembelajaran. Bandung: Pustaka Cipta.

Fitriyani. (2009). Perbandingan Hasil Belajar Siswa Dengan Menggunakan Metode Group Investigasi dan Talking Stick Pada Materi Pokok Reproduksi di Kelas XI MAN Kualuh Hulu Tahun Pelajaran 2009/2010. STKIP Labuhanbatu.

Gusti. (2011). Perbandingan Hasil Belajar Siswa Dengan Menggunakan Metode Observasi dan Jigsaw Pada Materi Pokok Reproduksi di Kelas XI SMA Negeri 1 Kualuh Selatan Tahun Pelajaran 2008/2009. STKIP Labuhanbatu.
Hamalik, Oemar. (2010). Perencanaan Pengajaran Berdasarkan Pendekatan Sistem. Jakarta: Bumi Aksara.

Hamdani. 2011. Strategi Belajar Mengajar. Bandung: Pustaka Setia.Kurniawan. (2011) Pengaruh Metode Pembelajaran Group Investigasi Terhadap Hasil Belajar Siswa Kelas XI MAN Kualuh Hulu. STKIP Labuhanbatu.

Kamaruddin, (2014). Perbedaan Hasil belajar Siswa Yang Dibelajarkan Dengan Menggunakan Model Pembelajaran Group Investigasi dan Observasi Pada Siswa Kelas VIII MTs Negeri Kualuh Hulu. STKIP Labuhanbatu

Nur. (2007). Strategi Pembelajaran Biologi: Teori, Praktik, dan Penelitian. Padang: UNP Press.

Nurleli. (2011). Pengaruh Strategi Pembelajaran dan Konsep Diri Terhadap Hasil Belajar Biologi Siswa SMA Negeri 1 Kualuh Hulu: STKIP Labuhanbatu.

Niwayan, M. (2012). Pengaruh Model Pembelajaran Group Investigasi Terhadap Penguasaan Konsep Biologi dan Hasil Belajar Siswa SMA ditinjau dari Minat Belajar Siswa. Artikel Penelitian, http:/www.wordpress.com. (diakses 27 Maret 2018).

Pratama. (2012). Keefektifan Penggunaan Pendekatan Kontekstual melalui Pembelajaran Observasi Terhadap Ketrampilan Berkomunikasi pada mata Pelajaran Biologi. STKIP Labuhanbatu.

Purba, S. 2010. Strategi Pembelajaran Kolaboratif Dalam Meningkatkan Kreativitas Belajar Mengajar. Medan: Jurnal Teknologi Pendidikan Pascasarjana Unimed Medan, Vol. 3, No. 1, April 2010, ISSN 1979-6692.

Syafitri. (2011). Pengaruh Model Pembelajaran Group Investigasi Terhadap Hasil Belajar Siswa SMP Negeri 2 Kualuh Selatan. STKIP Labuhanbatu.

Sanjaya, (2006) Belajar dan Hasil Belajar, Bandung: Remaja Rosdakarya.

Sagala, (2008). Strategi Pembelajaran Inovatif Kontemporer. Jakarta: Bumi Aksara.

Saiful. (2009). Strategi belajar dan mengajar. Jakarta: Grafindo. 
Sudjana, (2002), Metode Statistika, Bandung: Tarsito.

Slameto, (2010), Strategi dan Hasil Belajar. Jakarta : Rineka Cipta Karya.

Sardiman, (2009), Makna Pembelajaran. Jakarta : Rineka Cipta Karya.

Sukatma. Dkk. (1999). Buku Paket Biologi SMP Kelas VIII. : Jakarta : Yudistira.

Trianto. (2010). Mendesai Model Pembelajaran Inovatif-Progresif. Jakarta: Kencana Prenada Media Group.

Udin, S. Winaputra (2001). Penerpan Model Pembelajaran Observasi Terhadap hasil Belajar Siswa Kelas X SMP Negeri 3 Kualuh Selatan. STKIP Labuhanbatu.

Winkel (1996), Aktivitas Belajar dan Pembelajaran. Jakarta : Rineka Cipta Karya.

Widowati. (2007). Pengembangan Critical Thinking Melalui Penerapan Model Group Investigation Dalam Pembelajaran Sains. Yogyakarta: FMIPA Universitas Negeri Yogyakarta. (diakses pada 27 Maret 2017). 